\title{
Are we there yet? En route to professionalism
}

\author{
Andrea L. Meyer, Anné Leonard* \\ Division of Communication Management, Faculty of Economic and Management Sciences, University of Pretoria, South Africa
}

\begin{abstract}
The debate on the professional status of Communication Management/Public relations ${ }^{1}$ has been high on the worldwide agenda for decades. While previous research has focused on the criteria for professionalism in this field, practitioners and academics often question the efforts of professional associations to adequately address the issue of implementing systems to facilitate professional status. The emergence of the Global Alliance for Public Relations and Communication Management (GA) as an umbrella body for various regional professional associations, as well as the increased emphasis on regulation, standards and governance in all spheres of the global business environment, have led to renewed ques-tions about global efforts to achieve professional status for this field. This study focused on the goals and actions of member associations of the GA in relation to the question of profes-sional status. In order to understand the current state of affairs an exploratory qualitative approach was followed in which member associations were surveyed and their websites reviewed. The fact that fewer than half of the 27 member associations responded to the survey suggests that a study about this matter is not deemed particularly important and/or that the issue of professional status is not widely pursued. However, the associations that participated in this study agree that professional status is important. The study has also found that many similarities exist across continents in terms of the mechanisms utilized to achieve professional status. Codes of ethics, contributions to a body of the knowledge and the provision of professional training opportunities are regarded as quite important while divergent viewpoints exist in relation to issues like accreditation and a standardized tertiary curriculum.
\end{abstract}

Keywords:

Professional status

Professional associationsProfessionalism

Global Alliance for Public Relations and

Communication Management (GA)

Stockholm Accords

\section{Introduction}

The call for professional status of the communication management field and the licensing of practitioners has been a prominent issue in literature and a topic of debate among practitioners since 1968. The most well-known contributors to this debate are Grunig and Hunt (1984) who interpreted the four characteristics of a profession (an accreditation process, a unique code of ethics, a body of knowledge and specialized education and training) within the communication management context.

Thereafter, the series of Excellence Theory publications (1992-2007) made a significant contribution by stressing the contribution of communication management to the strategic success of organizations. These publications further emphasized the requirement of a more sophisticated knowledge base for practitioners in order to improve the efficiency of the

* Corresponding author at: Division of Communication Management, Department of Business Management, Faculty of Economic and Management Sciences, University of Pretoria, South Africa. Tel.: +27 124203399.

E-mail addresses: cafediva@gmail.com (A.L. Meyer), anne.leonard@up.ac.za (A. Leonard).

1 Public Relations is equal to Communication Management. The term Communication Management is used throughout. 
communication management functions in organizations, as well as the overall professional standing of practitioners in the business arena.

Recent events in the global communication management landscape highlight the continuous progress being made in relation to the question of professional status. The first was the formation of the Global Alliance for Public Relations and Communication Management (GA) in 2002 (following a six year pre-formation period) as a global umbrella organization aimed at unifying professional associations and addressing industry concerns. The GA's commitment to professionalism of the industry is clearly formulated in its mission statement (Global Alliance for Public Relations and Communication Management, 2012):

Representing 160,000 practitioners and academics around the world, the Global Alliance's mission is to unify the public relations profession, raise professional standards all over the world, share knowledge for the benefit of its members and be the global voice for public relations in the public interest.

Further advancement was made through the formal redefinition of the communication management field through the 2010 Stockholm Accords. According to these accords, practitioners are expected to be more closely involved with the strategic business issues of sustainability and governance, alongside their more traditional roles and areas of specialization. The revised expectations about the contribution of the communication management function flows from the recognition of the changes of the macro business environment. It can also be interpreted as an attempt to elevate it to the same level as more traditional professional areas of management for which accreditation and/or licensing is required.

Building on the foundation of the Stockholm Accords (2010), the Melbourne Mandate (2012) details the responsibilities of the communication management practitioner, stressing the importance of demonstrating professional responsibility through adherence to codes of conduct and professional standards, as well as the maintenance of standards of competence by continuous learning.

This article reports on the findings of an exploratory qualitative study among GA member associations regarding their sentiments about and policies aimed at achieving professional status for the communication management industry. The research was done by means of a qualitative survey sent to the presidents of the GA member associations, investigating the activities and policies of GA member associations in relation to the four dimensions of professionalism highlighted by Grunig and Hunt (1984), namely education and training, accreditation, disciplinary action and the existence of a robust body of knowledge (by means of research). Thematic analysis was done to compare the views of participating associations. Half of the GA member associations participated in the study (representing all the regions which are affiliated with the GA, except the Middle East. At the time of research, only one association in this region was a member of the Global Alliance, and this association chose not to participate.) The rest of this article describes the research, its background and its findings in detail.

\section{Literature review}

Professions are set apart from other career paths by their status and public respect which allow them a proportionate degree of autonomy in decision-making. In order for communication management practitioners to enjoy similar autonomy and recognition, professional status is essential. The following discussion highlights the key factors in the global communication management landscape that influence the professional status debate.

\subsection{Core elements associated with professional status in communication management}

Communication management practitioners and academics have debated the issue of professional status and steps to be taken to achieve this for a number of decades. Requirements to achieve this status are tied to two generic concepts, namely profession and professionalism. Smith (1958, p. 410) defines professions as "complex social institutions which select people of varied skills, often from several social strata, and organize them into different levels of operation and diverse interest groups", while Evetts (2011, p. 406) describes professionalism as "a distinctive and special way of controlling and organizing work and workers, with real advantages for both practitioners and clients... an occupational value".

To understand the global progress in thinking about the specific requirements for professional status in communication management and possible steps to be taken to achieve this status, a brief historical overview of views is necessary. Table 1 presents the evolution of thought about the dimensions associated with professionalism in the field between 1968 and 2008.

Table 1 summarizes the common threads in thinking about the issue: (i) education and/or training is a central concern, (ii) entrance to practice should be controlled by some kind of governing body, (iii) continuing education and professional development is important, (iv) a body of knowledge is pivotal, (v) adherence to professional norms should be upheld, (vi) ethics and codes of conduct should be binding, as well as (vii) professional associations ought to have disciplinary powers over practitioners.

Marston's (1968) definition is one of the earliest formal definitions of professionalism to be cited by experts like Ehling as part of the Excellence Study (Grunig et al., 1992). Grunig and Hunt's (1984) typology followed and is regarded as a seminal text in the field, being one of the first to formalize concepts around the strategic nature and role of communication management, oft-cited in academic works today, and remaining a core text prescribed to students of the field. 
Table 1

The evolution of criteria for professionalism in communication management.

\begin{tabular}{|c|c|}
\hline Author(s) & Key characteristics \\
\hline Marston (1968) & $\begin{array}{l}\text { i. A defined area of competence } \\
\text { ii. An organized body of knowledge of some consequence } \\
\text { iii. Self-consciousness } \\
\text { iv. Competence of entrants determined by controlled access } \\
\text { v. Continuing education } \\
\text { vi. Support of research } \\
\text { vii. Aid in education of competent replacement } \\
\text { viii. Independence }\end{array}$ \\
\hline Grunig and Hunt (1984) & $\begin{array}{l}\text { i. A set of professional values } \\
\text { ii. Membership in strong professional organizations } \\
\text { iii. Adherence to professional norms } \\
\text { iv. An intellectual tradition and an established body of knowledge } \\
\text { iv. Technical skills acquired through professional training }\end{array}$ \\
\hline Wylie (1994) & $\begin{array}{l}\text { i. A well-defined body of scholarly knowledge } \\
\text { ii. Practitioners completing some standardized and prescribed course of study } \\
\text { iii. Examination and certification by a governing body } \\
\text { iv. Oversight by a governing body with disciplinary powers }\end{array}$ \\
\hline Cameron et al. (1996) & $\begin{array}{l}\text { i. Intellectualism } \\
\text { ii. A code of ethics } \\
\text { iii. A comprehensive self-governing organization } \\
\text { iv. Greater emphasis on public service than self-interests such as profits } \\
\text { v. Performance of a unique and essential service based on a substantial body of knowledge } \\
\text { vi. Broad autonomy } \\
\text { vii. Practitioners guided by altruism } \\
\text { viii. Possible licensing }\end{array}$ \\
\hline Parsons (2004) & $\begin{array}{l}\text { i. Ethical values and conduct } \\
\text { ii. Mastery of a particular intellectual skill through education and training } \\
\text { iii. Acceptance of duties to a broader society than merely one's clients/employers } \\
\text { iv. Objectivity } \\
\text { v. High standards of conduct and performance }\end{array}$ \\
\hline Cutlip et al. (2006) & $\begin{array}{l}\text { i. Requires specialized education to acquire a body of knowledge and skills based on theory developed through } \\
\text { research } \\
\text { ii. Provides a unique and essential service recognized as such by the community } \\
\text { iii. Emphasizes public service and social responsibility over private interests } \\
\text { iv. Gives autonomy to and places responsibility on practitioners } \\
\text { v. Enforces codes of ethics and standards of performance through self-governing associations of colleagues } \\
\text { vi. Values are interpreted and enforced by disciplining those who deviate from accepted norms and prescribed } \\
\text { behaviours } \\
\text { vii. Professional societies set standards for specialized educational preparation, determine who is admitted into } \\
\text { practice, monitor practitioner performance against agreed-upon standards and confer levels of status on } \\
\text { practitioners }\end{array}$ \\
\hline $\begin{array}{l}\text { Niemann-Struweg and } \\
\text { Meintjies (2008) }\end{array}$ & $\begin{array}{l}\text { i. Specialized training in a specific body of knowledge } \\
\text { ii. Practice in a specific field } \\
\text { iii. Highly educated practitioners } \\
\text { iv. Social duty and responsibility } \\
\text { v. Ethical code }\end{array}$ \\
\hline
\end{tabular}

Niemann-Struweg and Meintjies (2008) did not apply Wylie's definition in their arguments that specialized training in a specific body of knowledge leads to practice in a specific field by well-educated practitioners, and that such practitioners have a social duty and responsibility to the reputation of the field. To fulfil the social requirement, practitioners have to adhere to relevant codes of ethics.

The description of requirements for professionalism published between 2004 and 2008 seems to reflect a deeper awareness of the connection between the field of communication management and its impact on society, thus the emphasis on ethics and possible means of achieving effective self-regulation.

Against this background Parsons (2004) emphasizes that it is important for the professional association to focus on ethical values and conduct. Cameron, Sallot, and Weaver-Lariscy (1996) highlight the debate on the licensing of communication management practitioners. While pointing out that professional status would give greater autonomy to practitioners, Cutlip, Center, and Broom (2006) stress that practitioners should also be fully aware of their responsibility in this context. Niemann-Struweg and Meintjies (2008) confirm many of the ideas and values that have been articulated since 1968. 
Table 2

Characteristics of the reflective strategist.

\begin{tabular}{ll}
\hline Strategist (Steyn) & Reflective (EBOK) \\
\hline - Strategic role at macro/societal level & $\begin{array}{l}\text { • Analyzing changing societal standards/values/viewpoints } \\
\text { and discussing them with organizational members to } \\
\text { adjust organizational values/norms regarding social } \\
\text { responsibility and legitimacy } \\
\text { - Inward communication }\end{array}$ \\
$\begin{array}{l}\text { - Conducting environmental scanning to gather information on stakeholders, } \\
\text { - Information acquisition/processing role of boundary spanner }\end{array}$ & $\bullet$ Aimed at developing mission/organizational strategies \\
- Outside-in approach to strategic management & Directed at the dominant coalition \\
- Performing the mirror function & \\
\hline Source: Steyn (2009). &
\end{tabular}

\subsection{Changes in the communication management arena}

Several changes in the communication management landscape highlight the need for and opportunities associated with pursuing professionalism: the emergence of the strategist role within a changing business environment, the growing prominence of umbrella bodies for professional associations and the ratification of the 2010 Stockholm Accords, followed by the Melbourne Mandate of 2012.

\subsubsection{Corporate citizenship and the communication strategist role}

The corporate citizenship business paradigm reflects an inclusive, transparent approach, as evident from the King III Report (IOD, 2009). The increasing scrutiny of organizational behaviour by all stakeholders has attracted a great deal of attention to corporate accountability. It is generally accepted that organizations earn their 'licence to operate' and prove their legitimacy through responsible actions and compliance with legal and ethical requirements (Doorley \& Garcia, 2011; IOD, 2009).

Communication management practitioners are required to function at a strategic level in order "to assimilate and integrate information necessary to the organization's longevity” (Steyn, 2009). Their value is seen as ensuring sustained mutual benefit for an organization and all its stakeholders (Grunig et al., 2003).

The role of communication strategist is also increasingly viewed as being the custodian of the organizations' reputation and is thus involved with the governance aspects of stakeholder relationships, as formulated in the King III Report (IOD, 2009). From this perspective, the communication strategist should be an integral part of boardroom level decision-making (Steyn, 2003, p. 179).

Furthermore, the strategic role is closely associated with the reflective role (incorporating elements of the reflective paradigm) as indicated in the European Body of Knowledge (EBOK) study (Steyn, 2009, p. 522). Thus the role of the communication 'reflective strategist' was born. Table 2 describes the characteristics of this role.

The scope and complexity of the communication strategist role, and the associated responsibilities such a role player has towards an organization, clients and society, seem to underscore the need for practitioners (also those who are working towards strategic level positions) to enjoy official recognition and sanction as provided for through professional status.

\subsubsection{The growing prominence of umbrella bodies for professional associations}

In communication management, the professional association may contribute to professionalism through its advocacy of the profession within the corporate world (Le Roux, 2011).

Noordegraaf (2011, p. 467) argues that professional associations are important in social organizing and decreeing the manner in which professions themselves are viewed and shaped. These associations contribute to the "demarcation and institutionalization of occupational practices, acknowledged but not controlled by outsiders". Regional associations (for specific sub-continents or continents) and global associations create platforms for participants to engage with one another on important industry matters. These associations generally aim to enlarge the profession's body of knowledge, govern accreditation processes for practitioners, contribute to the education of practitioners and enforce codes of conduct and ethics (Le Roux, 2011; O Connor \& Falconi, 2005; Sha, 2011). Membership of any kind of professional association is usually voluntary (Niemann-Struweg \& Meintjies, 2008).

The GA is the only international body in the field of communication management that seeks to address issues affecting professional bodies per se and not individual practitioner issues. International umbrella associations that focus on individual practitioner issues include the International Public Relations Association (IPRA), the International Association for Business Communicators (IABC) and the Corporate Communication Institute (CCI). According to the GA website (2012) its vision is "both to lead to and serve the PR and communication management profession at the international level by defining universal principles that unite our professional associations and their members". 


\subsubsection{The 2010 Stockholm Accords and 2012 Melbourne Mandate}

The Stockholm Accords (2010) together with the Melbourne Mandate (2012) form a set of comprehensive guidelines of the roles and responsibilities of the communication management professional (Global Alliance for Public Relations and Communication Management, 2012). These documents signal a final departure from a tactical orientation in defining the scope of the professional field and emphasize the issues of sustainability and governance (strategic concerns within business), while providing broad principles for the manner in which the communication management/public relations 'professionals' should deal with specific aspects. The very use of the term 'communication professional' suggests that the ideal for communication practitioners is to think of themselves as nothing less than professionals.

A review of the governing principles of both these documents further suggests a need for practitioners with much more than just a 'basic education' or 'training' background. The complexity of the global business environment and the associated corporate risks underscore the need for practitioners who are officially sanctioned by a global or regional body. The very fact that the professional status of the communication management field continues to be on the agenda, confirms the need for continued research on the matter.

\section{Research questions}

This study focused on two research questions:

$R Q 1$ : Do member associations of the GA support the professionalization agenda?

RQ2: What specific mechanisms have the GA member associations instituted in order to address issues pertaining to professionalization?

\section{Methodology}

\subsection{Research approach}

A qualitative research approach was followed since it was a small scale exploratory study. The research approach focused on "phenomena occurring in natural settings and studying these phenomena in their full complexity, acknowledging multiple truths within these contexts" (Leedy \& Ormrod, 2005, p. 134). The complex dynamics that determine how different countries' professional associations approach the issue of professional status validated the choice of an exploratory qualitative research approach for this study.

\subsection{Sampling design}

The member associations of the GA formed the population for the study since this umbrella body strongly supports efforts towards the professional status of the field, thus the sampling is categorized as purposive (Babbie \& Mouton, 2001, p. 166).

\subsection{Collection of evidence}

The presidents, vice-presidents and directors of GA member associations were invited to participate in an electronic survey (through SurveyMonkey). Thirteen of the 27 members of the GA participated in this study, which means that a $48 \%$ response rate was achieved. The qualitative survey instrument consisted of sections focusing on (i) general support for professionalism, (ii) education and training/professional skills development, (iii) accreditation, (iv) disciplinary action and (v) contributions to the general body of knowledge.

The websites of all GA member associations were used as a second source of evidence to investigate two issues in the questionnaire, namely (i) codes of ethics/conduct and (ii) research focus areas from the annual conferences of 2010 to 2012.

\subsection{Analysis techniques}

Thematic analysis (Boyatzis, 1998) was used in analyzing the survey responses. A matrix approach was followed for the review of the websites. These results were triangulated to arrive at the overall results and conclusions of the article.

\subsection{Measures for scientific soundness}

The four criteria for scientific soundness in qualitative research, as suggested by Babbie and Mouton (2001, pp. 274-278), governed this study. Credibility was sought through the triangulation of data from the qualitative survey and matrix analysis of websites. Referential adequacy was sought through the utilization of public documentation from each of the associations and cross-referencing of these with survey data. A twofold process was followed to ensure transferability, i.e. purposive sampling and a 'thick' (context-rich) description. Confirmability requires the completion of a pilot study, the availability of raw data for external review, as well as the methodical development of data collection instruments and the reconstruction and synthesis of research products (themes, findings, conclusions and report). The last criterion, dependability, 
depends on the continuous involvement of an auditor (subject expert). This was achieved by involving a more experienced researcher/academic.

\subsection{Limitations}

This exploratory study depended on a small population (i.e. one segment of all national and international professional associations in Communication Management/Public Relations), while only half of the population participated in the study. Results may therefore not be generalized to the entire population.

\section{Results}

The findings are based on the data collected from survey responses of 13 associations and an elementary content analysis of the 27 Global Alliance member associations' websites. The most pertinent and/or unique perspectives are also highlighted throughout in the form of verbatim quotes. (All results are reported according to the order in which geographical regions are listed in Table 3, i.e. Africa, Australasia, Europe, North America, South America and one globally representative association.)

\subsection{Demographics}

Demographic details refer to two main categories, namely those of individual respondents in their capacity as presidents/vice-presidents and individual associations.

Ten of these individuals were female and three male. Their highest academic qualifications ranged between doctorates (3), specialized master's degrees (6), MBAs (2), a bachelor's degree (3) and a diploma (1). These facts suggest that contributions of practitioners with advanced postgraduate degrees are valued in terms of leading professional associations.

Details about the participating associations in this study are already listed in Table 3. This table specifies countries which were represented, the official names of these associations and the year in which they were established. The oldest associations to participate in this study are PROCOM (Finland) and PRSA(USA), which were both started in 1947. The youngest is PRCAMALAYSIA which was started in 2010. Table 3 also lists the associations from New Zealand and Argentina as the oldest in their respective geographical regions.

\subsection{Support for professionalization}

Almost all (11) of the participating associations responded to this question.

The view from PRISA (South Africa) is that "legislation - and global legislation for all in the profession is important. Like engineers, accountants and medical professionals, PR professionals must be in a sense 'forced' to legislate to 'enforce' professionalization." Specific activities mentioned in the pursuit of professionalization included PRISA's involvement in education and training, continuing education (on a continuing professional development training points system), research with tertiary educational institutions and students, the accreditation processes offered (CPRP, APR), as well as lobbying for regulation.

Table 3

Participating professional associations.

\begin{tabular}{|c|c|c|}
\hline Regions and countries & Associations & Year established \\
\hline \multicolumn{3}{|l|}{ Africa } \\
\hline South Africa & Public Relations Institute of Southern Africa (PRISA) & 1955 \\
\hline \multicolumn{3}{|c|}{ - } \\
\hline Malaysia & Public Relations Consultants' Association of Malaysia (PRCAMALAYSIA) & 2010 \\
\hline New Zealand & Public Relations Institute of New Zealand (PRINZ) & 1954 \\
\hline \multicolumn{3}{|c|}{ 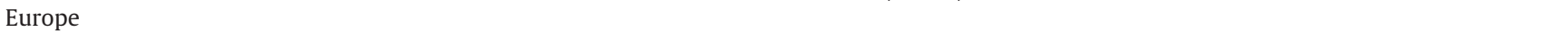 } \\
\hline Estonia & Estonian Public Relations Association (EPRA) & 1996 \\
\hline Finland & Finnish Association of Communication Specialists (PROCOM) & 1947 \\
\hline Germany & German Public Relations Association (DPRG) & 1958 \\
\hline Spain & Asociación de Directivos de Comunicación (DIRCOM) & 1992 \\
\hline Sweden & Swedish Public Relations Association (SPRA) & 1950 \\
\hline \multicolumn{3}{|l|}{ North America } \\
\hline Canada & Canadian Public Relations Society (CPRS) & 1948 \\
\hline USA & Public Relations Society of America (PRSA) & 1947 \\
\hline \multicolumn{3}{|l|}{ South America } \\
\hline Argentina & Professional Council of Public Relations of Argentina (RRPP) & 1958 \\
\hline Brazil & Brazilian Association of Business Communication (ABERJE) & 1967 \\
\hline \multicolumn{3}{|l|}{ Global } \\
\hline International & International Association of Business Communicators (IABC) & 1970 \\
\hline
\end{tabular}


According to PRCAMALAYSIA "the industry should be self-regulating and not governed by any country-specific laws. However, the industry is still in its growth phase in Malaysia." Professionalization is pursued through the training of young practitioners and setting guidelines for the industry at large through various means, including a code of ethics. The association is involved in lobbying for further self-regulation of the industry since the industry is still growing in that country.

PRINZ (New Zealand) emphasizes the importance of its RiVER professional development programme and the APR programme for accredited public relations providers. Regular training sessions are offered in all main centres.

Both EPRA (Estonia) and PROCOM (Finland) emphasize the importance of networking in their approaches. EPRA organizes monthly meetings and discussions while PROCOM states, "[W]e support professionalization through facilitating discussion on selected topics among members, but also in the whole society through media and networking, offering services and education for members."

DIRCOM (Spain) offers networking breakfasts and communication workshops, and actively participates in research projects. Furthermore, "the Association, in collaboration with the EOI Escuela de Organización Industrial, organizes monthly training sessions, eminently practical, which examine various fields of corporate management and institutional communication with the aim of contributing to the professional development of direct communication... Dircom also produces various publications, of which the best known is the Communication Yearbook, which has already reached its fifteenth edition."

The SPRA (Sweden) lists training, research, engaging in professional issues, and influencing curricula at universities as activities undertaken in support of professionalization.

CPRS (Canada) argues that "it's a work in progress. There are deep divisions in Canada as to whether accreditation and accreditation maintenance should be mandatory, and whether the professional should be regulated (licensed)." The association offers webinars, an annual national conference, and local professional development programmes organized by chapter societies, and requires members to adhere to a code of professional standards.

PRSA (USA) states, “[W]e provide training, set standards of excellence and uphold principles of ethics for the global public relations profession." This association regards itself as a leading voice in the industry and claims that "we also advocate for greater understanding and adoption of public relations services, and act as one of the industry's leading voices on the important business and professional issues of our time. To help members navigate ethics principles and applications, the society created, and continues to maintain, the PRSA code of ethics. Members pledge to core values, principles and practice guidelines that define their professionalism and advance their success when they agree to operate according to the code."

RRPP (Argentina) notes that they support the practice of prioritizing candidates with master's and doctoral degrees, and that they permit executives from the industry to spend time on the association's activities. The association also offers networking opportunities, lobbies for the profession and presents conferences.

The IABC (International) mentions that their publications and conferences are a means of sharing information on best practices, while an awards programme recognizes professional excellence. The association's code of ethics, the accreditation process, and research projects complete the list of activities that support professionalization.

\subsection{Education and training}

This dimension consists of two sub-questions, namely skills development and tertiary education.

\subsubsection{Continuing education and professional skills development}

Only six associations responded to this question.

These associations present both their own training programmes, while also frequently collaborating with tertiary institutions.

PRISA (South Africa) offers both short and accreditation courses for professionals, as well as full qualifications through its ProVox centre. This entity now functions independently, but with close ties to the association.

Four European associations responded to this question. EPRA (Estonia) cites university collaboration as one of its main activities. PROCOM (Finland) presents its own professional courses, collaborates with the Helsinki University and interacts with other educational institutions in their 'Educational Policy Forum'. They also work with the NGO sector and are negotiating cooperation with other organizations. DIRCOM (Spain) has strong links with both the Escuela de Organización Industrial and Instituta de Empresa and regularly facilitates several large-scale seminars and workshops, the latest focusing on social media. The Spra (Sweden) runs approximately 50 different training programmes annually ranging from basic communication issues to executive programmes.

In South America, the RRPP (Argentina) has firm relationships with "almost every university involved in education in communications".

\subsubsection{Standardization of tertiary curricula}

The three responses to this question suggest that there is no standardized curriculum per region or country.

PRISA (South Africa) endorses a number of tertiary programmes, receiving endorsement in return, while "further work is needed in this area". Procom (Finland) has lent its support to two institutions, but adds that "approval is more brand 
value than based on a real monitoring type of follow up". And SPRA (Sweden) reports that "not much is done" in this regard.

\subsection{Accreditation}

Three sub-sections contribute to the overall picture regarding accreditation, namely the importance thereof, actual processes and endorsement of these processes.

\subsubsection{The importance of accreditation}

Only 11 responses were recorded: 10 in favour of accreditation and one regarding it as "not important".

PRISA (South Africa) was the only association to elaborate on the issue: "It will become increasingly important as the Global Alliance (GA) and the professional associations within it (of which PRISA is one), increases (sic) pressure from a global perspective. Global and regional accreditation, as well as legislation, is important and to an extent necessary."

\subsubsection{Accreditation processes}

This item received nine responses.

PRISA (South Africa) offers the APR examination through the CIPR. This system is supported through their CPD point system. PRCAMALAYSIA (Malaysia) offers no accreditation process, as the association believes in self-regulation. PROCOM (Finland) argues that a centralized accreditation process is viewed as problematic in the context of Finnish or even Nordic cultures, although they would be open to suggestions as a result of the globalization efforts in the field.

Neither DIRCOM (Spain) nor SPRA (Sweden) offers accreditation processes, although the SPRA emphasizes that "our training programs are considered as high quality by the Swedish Communication Industry".

The CPRS (Canada) accreditation process requires that a work sample be submitted. It also requires a formal examination with short and long essay questions and an oral component. A mark of $65 \%$ or above is required to pass this accreditation examination.

The RRPP (Argentina) reported that no accreditation process has been instituted as "there is not consensus because of the position of the academic sector, which doesn't feel comfortable with an evaluation made by a professional association."

The IABC (International) process, similar to CPRS (Canada), has three components: a portfolio of two projects, a written examination and an oral examination.

\subsubsection{International endorsement of the accreditation}

Only three associations replied to this question.

PRISA's (South Africa) process is endorsed by both the Global Alliance (GA) and the Chartered Institute of Public Relations (CIPR) in England. The CPRS (Canada) accreditation is endorsed by the GA. The process which the ABERJE (Brazil) follows is endorsed by the International Public Relations Association (IPRA). Finally, the IABC's process is endorsed by a Canadian university.

\subsection{Disciplinary action}

Professional membership as a requirement to enter practice, actual disciplinary measures taken by professional associations and the codes of ethics were explored to form a holistic answer.

\subsubsection{Professional membership}

Eight associations responded to this item. The majority (6) stated that it is not necessary to be a member of the association in order to practise communication management in the region. One response rejected the idea outright and one response reflected uncertainty about this issue.

PRISA (South Africa) indicated that although it is not necessary at this stage, membership will become increasingly important as relevant legislation is introduced. DIRCOM (Spain) stated that membership is a prerequisite. The website analysis revealed that membership of ABERJE (Brazil) is required in order to enter practice.

\subsubsection{Disciplinary measures in the association}

There were only five responses to this question, which may suggest that few associations act when codes of ethics are breached.

PRISA (South Africa) stated that practitioners who do not adhere to ethical codes and bring the profession and their association into disrepute may be struck off the list of practitioners and blacklisted. However, "as there is no legislation in store at the moment, this is still a 'toothless' exercise".

In PROCOM (Finland), ethical contraventions are first reported to the association, who initiate confidential discussions with the organization or individual before making the issue public. SPRA (Sweden) members may forfeit their membership of the association if they act in contravention of the association's regulations.

At CPRS (Canada), a Judicial and Ethics Committee reviews all complaints brought against members of CPRS. This is also the case at the IABC (International): "If the committee determines that a violation of the code of ethics has occurred, the 
committee chair will counsel the offender, with the aim of educating him or her about why the behaviour in question is a violation. Upon advice of legal counsel, we do not cancel the individual's membership unless he or she is convicted of a crime."

\subsubsection{Review of codes of ethics}

The results of the review of the different elements (18) from all codes of ethics/conduct of the participating associations are presented in Table 4.

All 13 participating associations pay attention to 'honesty and trustworthiness'. The second most prominent aspect (with 11 associations mentioning it) was 'professionalism, expertise and professional development'. Two aspects, namely 'transparency' and 'freedom of expression and information' were mentioned by nine associations. In similar fashion 'confidentiality' and 'conflict of interest' clauses were present in eight codes of ethics. Seven associations listed an 'integrity' clause, while six listed 'remuneration - salary and not kickbacks'. The prominence of these dimensions suggests that there is a real concern for and efforts to pursue high ethical standards by including the 'major issues' across the board.

The dimensions least often listed in the codes of ethics were 'fairness' and 'human rights' (five mentions each), 'overpromise' and 'legality' (four mentions each), 'accuracy' and 'dialogue and mutual benefit' (three mentions each), 'collaboration' and 'contribution of reputation to the profession' (two mentions each), while 'open communication' was listed by one association only. Although these dimensions are part and parcel of ethical codes, they seem to represent (also in frequency) 'minor' concerns.

\subsection{Body of knowledge}

The body of knowledge is the last of Grunig and Hunt's (1984) requirements for professional status which was investigated in this study. It was also investigated by means of multiple questions, i.e. general contribution to a body of knowledge, involvement in commissioned research and a review of the most recent conference themes.

\subsubsection{Contribution to a defined body of knowledge}

The seven responses to this item suggest that associations view this facet as being an important aspect of their contribution to the profession.

According to PRISA (South Africa) "it is a documented fact that PRISA is the association in the world with the best documented body of knowledge - refer to the Bled Manifesto on the PR body of knowledge through to the Global PR books."

In Europe, ProCom (Finland) highlights its role as a 'kiosk' to collect and disseminate information for all interested parties, but notes that universities do not always have the resources or interest to act, while Dircom (Spain) emphasizes their involvement in organizing conferences. SPRA (Sweden) indicates extensive involvement in initiating and conducting research.

CPRS (Canada) cites the development of their 'Pathways to the Profession' framework - a framework which was developed through research in order to identify key course outcomes in tertiary level communication management educational programmes.

The IABC runs a Research Foundation which, according to their response, "commissions research with the purpose of growing the body of knowledge. The emphasis is on topics and a focus that can provide actionable strategies for our members as opposed to academic research."

These responses seem to confirm that associations (at different points in time) still value the expansion of the body of knowledge, both by commissioning research and facilitating cross-pollination between practitioners and the academic research arena.

\subsubsection{Commissioned research}

When associations commission research on topical issues (like online or internet-based practices), they arguably help practitioners in the most tangible form. Such research also bridges the gap between purely academic research and practitioners.

Only seven associations responded to this question.

PRISA (South Africa) lists public relations, development and health communication, lobbying, government communication, corporate governance, stakeholder engagement and reputation management as research topics covered in the past five years.

ProCom (Finland) states: "Social media research is one of the most popular areas in the past 5 years. We collaborate in research tailored by $\mathrm{PhD}$ students (like leadership and communication) or university level institutions to develop futureoriented courses... . The next research topic is about lobbying and will be conducted by a private lobbying organization invited and co-branded by ProCom."

Dircom (Spain) focuses on five areas: "(i) the Spanish model of management and reporting of intangibles for a director of communication, (ii) the current state of the internal communication function, (iii) the development of domestic organizations with regard to managing their brands, (iv) the implementation and consequences of the responsibility business in enterprises and (v) the state of communication in Spain." 
Table 4

Synopsis of the dimensions of different codes of ethics.

\begin{tabular}{|c|c|c|c|c|c|c|c|c|c|c|c|c|c|c|c|c|c|c|c|}
\hline \multirow{2}{*}{$\begin{array}{l}\text { Geographical } \\
\text { regions/ } \\
\text { countries }\end{array}$} & \multirow[t]{2}{*}{ Associations } & \multicolumn{18}{|c|}{ Elements of codes of ethics } \\
\hline & & Accuracy & $\begin{array}{l}\text { Colla- } \\
\text { boration }\end{array}$ & $\begin{array}{l}\text { Confiden- } \\
\text { tiality }\end{array}$ & $\begin{array}{l}\text { Conflict } \\
\text { of } \\
\text { interest }\end{array}$ & $\begin{array}{l}\text { Contribute } \\
\text { to } \\
\text { positive } \\
\text { reputa- } \\
\text { tion of } \\
\text { profes- } \\
\text { sion }\end{array}$ & $\begin{array}{l}\text { Dialogue } \\
\text { and } \\
\text { mutual } \\
\text { benefit }\end{array}$ & $\begin{array}{l}\text { Do not } \\
\text { guaran- } \\
\text { tee } \\
\text { quantita- } \\
\text { tive } \\
\text { results } \\
\text { (over- } \\
\text { promis- } \\
\text { ing) }\end{array}$ & $\begin{array}{l}\text { Fairness } \\
\text { (Clients, } \\
\text { society } \\
\text { and } \\
\text { fellow } \\
\text { practi- } \\
\text { tioners) }\end{array}$ & $\begin{array}{l}\text { Freedom } \\
\text { of expres- } \\
\text { sion and } \\
\text { informa- } \\
\text { tion }\end{array}$ & $\begin{array}{l}\text { Honesty } \\
\text { and } \\
\text { trustwor- } \\
\text { thiness }\end{array}$ & $\begin{array}{l}\text { Human } \\
\text { rights }\end{array}$ & $\begin{array}{l}\text { Indepen- } \\
\text { dence }\end{array}$ & Integrity & Legality & $\begin{array}{l}\text { Open } \\
\text { competi- } \\
\text { tion }\end{array}$ & $\begin{array}{l}\text { Profe- } \\
\text { ssionalism, } \\
\text { expertise } \\
\text { and pro- } \\
\text { fessional } \\
\text { develop- } \\
\text { ment }\end{array}$ & $\begin{array}{l}\text { Remune- } \\
\text { ration - } \\
\text { salary, } \\
\text { not } \\
\text { kickbacks }\end{array}$ & $\begin{array}{l}\text { Trans- } \\
\text { parency }\end{array}$ \\
\hline
\end{tabular}

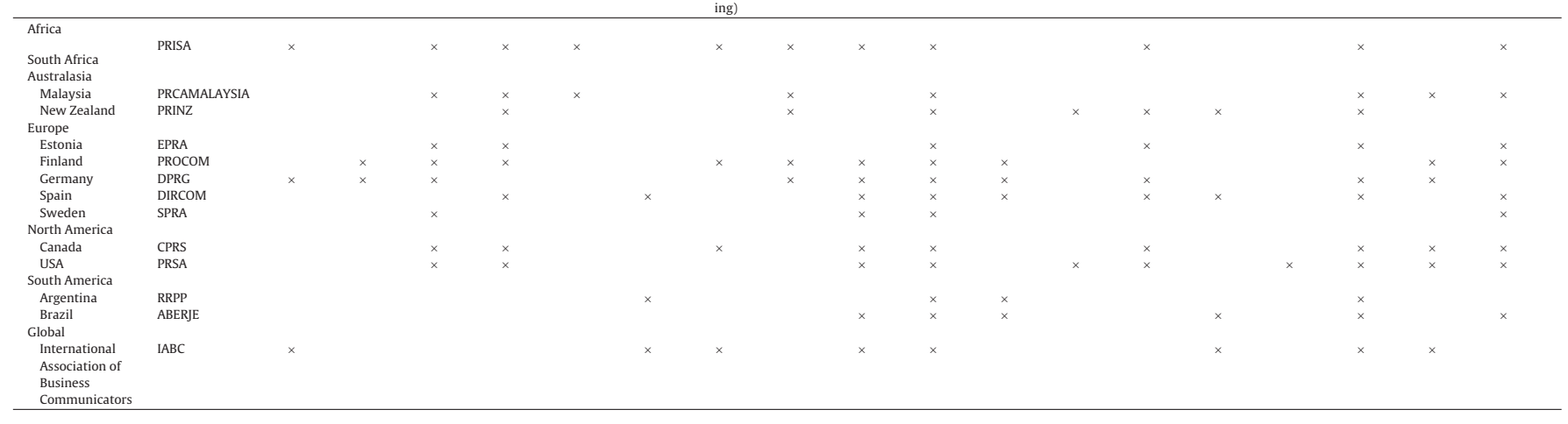


SPRA (Sweden) lists topics such as communicative organizations, lobbying, communicative leadership, social media and internal communication.

CPRS (Canada) cited its involvement in gap analyses, while lobbying, Web 2.0 and the field of Corporate Social Responsibility were highlighted by RRPP (Argentina).

The IABC, through its Research Foundation, hosts a sophisticated webpage on which all its research projects can be found. The most recent report it published was a survey on employee engagement, while research was being done on the structuring of a communication department and best practices therein. The ever-changing strategic environment in which practitioners operate confirms the need for these types of research projects and the utilization of the results by practitioners.

\subsubsection{Review of conference themes}

The conference themes of the annual practitioner events of all participating associations between 2010 and 2012 were reviewed. There seems to be two broad topics shared by the participating associations at different points in time, namely the 'power of PR' and 'future practices'. Other conference themes range from regional interest to universal concerns such as CSR. A conversion of themes seems to have emerged for 2012 with the emphasis placed on 'PR 2.0', 'Digital PR' and 'social media' and future challenges.

\section{Discussion}

The discussion has a holistic focus and deal with each of the five broad dimensions described in Section 5.

\subsection{Support for the professionalization agenda}

There was general consensus among participants in this study that professional status is still on the agenda and should be pursued. However, the relatively low response rate from the GA members in relation to this study begs the questions whether this is a truly global concern, an issue deserving urgent action, or an issue that is steeped in history and pursued as a matter of tradition.

The oldest associations, like PRSA and PRISA, necessarily have longer histories and have contributed to the global understanding of the professionalization debate. The youngest associations apparently do not have to go through the labour pains of older associations in order to be relevant, as is evident from the progress PRCAMALAYSIA has made in a very short time. An interesting finding is that research areas are converging. The same could happen in future with regard to the pursuit of professional status.

The reasons for supporting the quest for professional status vary and they are open to multiple interpretations. Some associations seem to stick with the issue of professionalization as a necessary 'tick-box exercise', while others urgently want to press towards legal registration of practitioners before entering practice. No mention was made of (i) the 2010 Stockholm Accords, (ii) the changing business environment, (iii) the communication strategist role or (iv) the philosophy of corporate citizenship as reasons for working towards professional status.

\subsection{Specific mechanisms for achieving professional status}

According to the participating associations there is no universally accepted manner in which professional status is sought. The different strategies of various country-specific professional associations reflect different priorities. Associations differ on (i) whether the communication management field should be self-regulating, (ii) whether accreditation is an 'adequate process' (to qualify as a fully recognized profession) and (iii) whether the field needs to be legislated in order to achieve full professional status (and recognition). Several contextual realities influence the position of these associations, namely their overall contributions (global, regional and country specific) to the global field, a sense of urgency to achieve professional status, the creation of mechanisms to legislate the industry and cultural norms that influence the world view of practitioners.

No mention was made of a universally standardized curriculum, a topic of debate over many decades whenever professional status was discussed. Most associations are actively pursuing some sort of programme to support the professional development of practitioners. The degree of similarity in the participating associations' underlying approach (as seen in practices) suggests that a universally accepted 'model' could possibly emerge in future.

A code of ethics still serves the benchmark for professional standards for most associations, yet only a handful of elements appear in all the codes reviewed in this study. It seems that if a truly global effort were to be made towards professional status, this issue must be addressed.

Most associations still contribute to their country-specific and regional body of knowledge, which implies that the field is not stagnant. It is encouraging to see the wide variety of 'hot topics' for which research was commissioned by associations. While some associations viewed research as the outcome of collaboration with universities, others appeared to prefer applied and introspective research. Conferences are also a means of collecting and disseminating research findings to members - a mechanism for sharing the body of knowledge. 


\section{Recommendations}

Managerial:

(i) If professional status is sought in all earnest, there should be continuous dialogue between a multitude of stakeholders in order to align such a vision with the views from around the globe. The current differences between associations seem to stem from the country-specific visions for the field.

(ii) A possible strategy that could advance the notion of professional status from the bottom up could be to make membership of a country-specific professional association compulsory for all entry-level students (certificate, diploma, degree or advanced degree) right from the start.

(iii) Umbrella bodies such as the GA or continental associations (e.g. EUPRERA) should be strengthened and mandated to provide a universal framework for accreditation and related matters. A global register of practitioners (however junior or senior) could be created in order to advance the status of practitioners as being well educated/trained and meeting all the other requirements for practice.

Research:

(i) This study should be replicated and the opinions from the remaining GA member associations sought.

(ii) This study should also be expanded to incorporate a vast quantitative survey in which many more countries, other than those affiliated with the GA, should participate.

\section{Conclusion}

Claims cannot be made that most or all professional associations that align themselves with the GA are in favour of or against professional status of the industry. The fact that more than half of the GA member associations did not respond to invitations to participate in this study can be interpreted as sending an equally strong message of neutrality towards the professionalization agenda.

Those associations actively pursuing the professionalization of the industry do so by means of a variety of mechanisms. The different histories of regional and country-specific associations, the unique societal and business realities within these regions, and the varied expectations about the contribution of practitioners in the business world dictate just how actively professional status is pursued. It seems that global debates are essential in arriving at a possible global roadmap towards professional status for the industry.

\section{References}

Babbie, E., \& Mouton, J. (2001). Practice of social research. Bath: Oxford Press.

Boyatzis, R. E. (1998). Transforming qualitative information: Thematic analysis and code development. Sage: Thousand Oaks, CA.

Cameron, G. T., Sallot, L. M., \& Weaver-Lariscy, R. A. W. (1996). Developing standards of professional performance in public relations. Public Relations Review, 22(1), 43-61

Cutlip, S. M., Center, A. H., \& Broom, G. M. (2006). Effective public relations (9th ed.). Upper Saddle River, NJ: Pearson Education Inc.

Doorley, J., \& Garcia, H. F. (2011). Reputation management (2nd ed.). New York: Routledge.

Evetts, J. (2011). A new professionalism? Challenges and opportunities. Current Sociology, 59(4), 406-422.

Global Alliance for Public Relations and Communication Management. (2012). Global Alliance for Public Relations and Communication Management. [Online]. Available from: http://www.globalalliancepr.org/content/1/1/homepage (accessed 30.01.12)

Grunig, J. E., \& Hunt, T. (1984). Managing public relations. Orlando, FL: Harcourt Brace Jovanovich Publishers.

Grunig, J. E., Grunig, L. A., \& Dozier, D. M. (1992). Excellence in public relations and communication management. New Jersey: Lawrence Erlbaum Associates. Grunig, J. E., Grunig, L. A., \& Dozier, D. M. (2003). Excellence in public relations and effective organizations. New Jersey: Lawrence Erlbaum Associates. IOD (Institute of Directors). (2009). King Report on Corporate Governance. Johannesburg: IOD.

Leedy, P. D., \& Ormrod, J. E. (2005). Practical research: Planning and design (8th ed.). New Jersey: Pearson Prentice Hall.

Le Roux, T. (2011). The contribution of South African corporate communication practitioners to organizational performance. Potchefstroom: North-West University (Unpublished DPhil dissertation).

Marston, J. (1968). Hallmarks of a profession. Public Relations Journal, 24(7), 8-10.

Melbourne Mandate.(2012). [Online]. Available from: http://melbournemandate.globalalliancepr.org/wp-content/uploads/2012/11/Melbourne-MandateText-final.pdf (accessed 01.10.13)

Niemann-Struweg, I., \& Meintjies, C. (2008). The professionalism debate in South Africa. Public Relations Review, 34(3), 224-229.

Noordegraaf, M.(2011). Remaking professionals? How associations and professional education connect professionalism and organizations. Current Sociology, 59(4), 465-488.

O' Connor, N., \& Falconi, T. M. (2005). Profiling the regulatory environment of public relations practice in the UK, Italy and South Africa. Journal of Communication Management, 9(1), 28-55.

Parsons, P. J. (2004). Ethics in public relations: A guide to best practice. London: Kogan Page.

Sha, B. (2011). Accredited vs. non-accredited: The polarization of practitioners in the public relations profession. Public Relations Review, 37, 121-128.

Smith, H. L. (1958). Contingencies of professional differentiation. The American Journal of Sociology, 63(4), 410-414.

Steyn, B. (2003). From strategy to corporate communication strategy: A conceptualization. Journal of Communication Management, 8(2), 168-183.

Steyn, B. (2009). The strategic role of public relations is strategic reflection: A South African research stream. American Behavioral Scientist, 53(4), 516-532.

Stockholm Accords. (2010). [Online]. Available from: http://www.globalalliancepr.org/website/sites/default/files/fedeles/Stockholm\%20Accords/ The\%20Stockholm\%20Accords_draft_June\%2015_new\%20CI.pdf (accessed 11.10.12).

Wylie, F. W. (1994). Commentary: Public relations is not yet a profession. Public Relations Review, 20, 1-3. 